\title{
SOCIALIST SUNDAY SCHOOLS IN BRITAIN,
} 1892-1939

Recent interest in the social conditions which underlay the emergence in Britain of independent labour politics in the last decade of the nineteenth century has thrown a good deal of light on the Labour Church movement. ${ }^{1}$ Dr. E. J. Hobsbawm, in a characteristically stimulating chapter of his Primitive Rebels, set the Labour Churches within the context of the "labour sects" which he isolates as a phenomenon of nineteenth century Britain and defines as "proletarian organisations and aspirations of a sort expressed through traditional religious ideology". ${ }^{2}$ The concentration of academic attention on the Labour Church has given rise to the mention of a little known phenomenon of the British working-class movement, Socialist Sunday Schools ${ }^{3}$ which, it is usually suggested, were little more than a fringe activity of the Labour Churches. It is the object of this paper to give some account of the history of Socialist Sunday Schools in Britain until 1939 and to suggest that they too constitute a "labour sect" cognate with the Labour Church but organisationally and geographically distinct from it and therefore representing an extension of the working-class sectarian tradition beyond the limits of the nineteenth century within which Hobsbawn seems to confine it. ${ }^{4}$

In the 1890 os the seeds laid in the previous decade by the propaganda of the Socialist Societies ${ }^{5}$ and the revelations of the social investigators

1 The most comprehensive survey of the Labour Church movement in Britain is to be found in an unpublished Ph. D. thesis by D. F. Summers, The Labour Churches and Allied Movements in the Late Nineteenth and early Twentieth Centuries (The University of Edinburgh, 1959). For recent published accounts of the movement see H. Pelling, Origins of the Labour Party, 1880-1900, 2nd. ed. (Oxford, 1965), pp. 125ff.; K. S. Inglis, Churches and the Working Classes in Victorian England ( 1963 ), Chapter VI.

${ }^{2}$ E. J. Hobsbawm, Primitive Rebels (Manchester, 1959), pp. 7, 1 $26 \mathrm{ff}$.

${ }^{3}$ Pelling, op. cit., pp. 136,138 ; Inglis, op.cit., p. 244.

4 Dr. Hobsbawm does not actually say that the phenomenon of the labour sect came to an end with the nineteenth century, but he suggests by implication that the Labour Churches were the last manifestation of the phenomenon and does not mention by name the Socialist Sunday School movement. Cf. Hobsbawm, op. cit., pp. r44ff.

5 The Social Democratic Federation (founded 1883 ) and the Socialist League which seceded from the Federation in $188_{4}$. Cf. H. Pelling, op.cit., pp. I 3 ff. 
like Charles Booth came to flower in an upsurge of working-class unrest. Working people began to question the basic assumptions of the age about social organisation. No longer was it possible for many of the thoughtful among the working class to believe that acceptance of the individualist ethic of competition would ensure the social betterment of the provident and self-reliant or to believe that the misery and suffering of the poor could be attributed to the moral and physical shortcomings of individuals. Society, they were coming to feel, must accept responsibility for the downtrodden and so organise itself as to bring about their social betterment. The spread of this new feeling in the Labour movement led in 1893 to the formation of the Independent Labour Party which represented a sharp revolt in working-class politics from the domination of the Liberal caucus. In the previous year John Trevor had founded in Manchester the first of the Labour Churches and this movement spread with the growth of independent labour politics through the North of England. This kicking over of the theological traces represented a revolt from middle-class domination in the chapels.

The Labour Churches were in the tradition of the labour sects of the nineteenth century. They drew their membership almost exclusively from the ranks of working-class men and women. They were democratic in organisation and gave to ordinary people opportunities to express themselves articulately through pulpit oratory and the experience of responsible office-holding. They had an important role, therefore, in the training of the native leaders of the working-class movement. What was new about the Labour Churches as a workingclass sect was the spirit in which the movement was brought into being. The members of the Labour Churches as distinct from John Trevor himself, ${ }^{1}$ showed little interest in the construction of a new theology. They generally rejected the conception of personal sin as the cause of suffering in this world and boldly asserted that suffering was the result of bad social organisation which, in terms of their own experience, meant the system whereby men had to work for wages within a context of free enterprise capitalism. Their aspirations were fixed not on life after death, but on the communist millennium.

The Socialist Sunday School movement sprang from the same conditions and shared the ethical outlook of the Labour Church members. Yet although the growth of a working-class sunday school movement owes much to the stimulus of Labour Church organisation, it was no mere sideshow of the Labour Churches. The origins of

\footnotetext{
${ }^{1}$ For a discussion of Trevor's theology and its relation to the Labour Church movement see S. Pierson, "John Trevor and the Labour Church Movement", in: Church History, $\operatorname{XXIX}(1960)$, pp. $460-477$.
} 
what came to be known as the Socialist Sunday School movement are to be sought, not in the North of England (to which the Labour Churches were virtually confined), but in the West of Scotland where they were associated with the emergence of independent labour politics. Moreover, Socialist Sunday Schools had an aim which Labour Church Sunday Schools never seem clearly to have formulated, namely, the conversion of a significant portion of the new generation of British youth to Socialism for the purpose of transforming British society by political and industrial action. Finally, the history of the movement is striking enough to alter the time-scale in which Hobsbawm has placed the "labour sects", a time-scale in which he appears to consider the Labour Churches as a late and final phase in the tradition of working-class religious movements in Britain. Socialist Sunday Schools were numerous and strong enough in the period covered by this essay to represent at least one more wave of labour sectarianism. Indeed one might go still further and argue that their revival after the First World War and their association in the inter-war period with extreme forms of Socialism represents yet another and perhaps the final flourishing of the "labour sect".

In this paper, therefore, I attempt to establish the position of the Socialist Sunday School movement in the tradition of the "labour sects". In demonstrating its origins and early development I attempt to show that it represented a second wave - or perhaps more accurately a strengthening of the first wave - of the spirit of revolt that led to the establishment of the Labour Churches. In tracing its history to 1939, by which time the evidence of its decline is incontrovertible, I attempt to show how the ideological attitude of the sect changed after the First World War in response to the altered social and economic circumstances of the nation.

By one of the ironies of historical accident the earliest recorded attempt to establish a Sunday School for the teaching of Socialism to children occurred in secularist-dominated London. Among the members of the Battersea branch of the Social Democratic Federation in 1892 was a certain Mrs. Mary Grey. ${ }^{1}$ Daughter of a Berkshire

1 Two sources provide an account of Mary Grey and her work in Battersea: I) A biographical sketch published in the Young Socialist, Apr., 1903. 2) A Ms. account dated 1952 of an interview with Mary Grey obtained in 1935 by Alfred Blackburn for the National Council of British Socialist Sunday Schools. The latter source is in the possession of Mr. J. Simmons, Sheffield, ex-President of the National Council. Henceforth, the Young Socialist is cited as YS. 
shopkeeper she had come to suffer unwonted distress in her married life by the illness and unemployment of her husband. Her early upbringing had been that of a Christian, but she had rejected Christianity in later life on the ground that Christians did not "follow the teachings of their ... master". ${ }^{1}$ While working in SDF soup kitchens she was profoundly moved by what she saw of the sufferings due to trade depression of the children in London's East End. It filled her with enthusiasm to make some more positive contribution towards the advance to Socialism. Her mind returned to the experiences of her youth as a sunday school teacher and she proposed that the Battersea SDF should establish a sunday school for the teaching of Socialism to children. It is indicative of the secularism of London Socialist circles that her plea fell on stony ground and she had to proceed with her plan single-handed. The reason she gave for her determination is significant: "I could see that unless we could teach the children, we should not make a very quick advance." was the idea that the transition to Socialism would depend upon the education of a new generation. In November, 1892, she held the first meeting of her sunday school in the SDF rooms, Battersea, attended by one girl and a boy. ${ }^{3}$ By 1903 she was still running the sunday school single-handed with an attendance of some ninety children. She was found to be teaching elementary ethics in the most practical manner: "What proper and becoming things to do on entering their homes: wipe their feet, ... ask mother whether they could help her and so on."4 Much later, the Socialist Sunday School movement was to honour Mary Grey as a precursor of their organisation. Her experiment was personal and isolated, however, and was not the stimulus for the creation of Socialist Sunday Schools in other parts of the country. In some ways it was similar to the handful of Cinderella Clubs run in the East End of London in the nineties, notably by the nurse, Sister Kerrison, a member of the West Ham Board of Poor Law Guardians. ${ }^{5}$

Cinderella Clubs were the brain-child of Robert Blatchford who had them organised and run in the early nineties to feed and clothe the ragged slum-children of the Lancashire textile towns. They were taken up by some Labour Churches as a philanthropic activity. In I 893 John Trevor, anxious to give the churches a more congregational and less political appearance, suggested that Cinderella children

1 YS, Apr., 1903.

Ibid.

${ }^{3}$ Ibid. The Blackburn Ms. states that Mary Grey's two daughters and a boy were present.

4 Y, Apr., Igo3.

5 Labour Leader, Feb., Oct., 1896. 
might be taught as well as fed. A committee of Cinderella workers met at Manchester with Trevor and Blatchford in attendance and drew up the following resolution:

"We propose to establish a Cinderella sunday school not to force into the children Labour Church ideas but, by means of interesting lessons on various subjects, to develop their thinking and imaginative faculties so that they may grow up to be what they were intended to be, men and women who will be able to some extent to take an intelligent interest in things which go on every day around them and thus mitigate some of the evils which are at present dwarfing and stunting their lives. Our idea of the school, therefore, is that it should be a place where the children can be trained to think and not merely to become Socialists or Labour Church members."1

The meeting marks the beginning of the working-class Sunday School Movement in Lancashire. The influence of Blatchford was important because it established a rationalist tradition which was never wholly absorbed into the developed Socialist Sunday School movement. The early pioneers of Socialist Sunday Schools found in Mary Grey's Battersea experiment a congenial expression of their own ethical outlook. As we shall see, they never accepted the rationalist approach taken up by the Manchester Cinderella committee. The aim of the latter was that children should be trained in the mental processes necessary to understand the society in which they lived, not to instill into them pre-conceived ideas about its ethical character.

That Socialist Sunday Schools developed not along rationalist lines, but along the lines of a working-class sect dedicated to the teaching of Socialism to children in the language of traditional Christian ethics was due to the influence of James Keir Hardie who was at this time thrown into prominence by his election to the House of Commons in 1892 as Member for South West Ham. Hardie had come to the point of questioning existing social arangements through the temperance agitation for prohibition of the liquor traffic. ${ }^{2}$ As a member of the Independent Order of Good Templars, he had early accepted the idea that social arrangements rather than personal weakness might be the primary cause of individual failure in self-improvement. The Order, moreover, placed great stress on the early training of children in correct conduct. By 1892 Hardie was declaring himself to be a Socialist. Moreover, as owner-editor of the Labour Leader, he had an eye to the good effect which a column specifically for children might

1 Summers, The Labour Churches and Allied Movements.

${ }^{2}$ CF. W. Stewart, J. Keir Hardie; A Biography (1923), pp. 7, 18. Stewart, however, does not consider the relevance of the Temperance movement to Hardie's development. 
have on circulation and in April, I 893, he began writing such a column monthly for his paper. ${ }^{1}$ Mixing principle with good business, he gave the column a strongly didactic flavour and in May, 1893, proposed the formation of a club to be called the "Crusaders", members of which should remember three things, namely: that men and women were created to enjoy life; that everything which hinders men and women from enjoying life is wrong and sinful: that it is our duty to remove these hindrances. ${ }^{2}$

The idea caught on and by July, 1895 Hardie had enrolled over one thousand children as Crusaders. ${ }^{3}$ By this time Hardie was urging some of his colleagues in Glasgow independent labour circles to take up the formal organisation of classes for Crusaders. ${ }^{4}$ Among this circle were several people later to win national reputations for themselves in the British labour movement, including $\mathrm{J}$. Bruce Glasier (afterwards President of the Independent Labour Party), his wife, Katherine Conway (already well known as a lecturer on Socialism) and Margaret MacMillan (who was to come to the fore as a social reformer in the field of child welfare). More important for the Socialist Sunday School movement in the long run - for the energies of these workers were soon to be absorbed by national politics - were second-rank adherents who achieved no national prominence, especially Archie McArthur (Hardie's personal friend), Lizzie Glasier(sister of Bruce Glasier) and Alex Gossip, Glasgow and District Secretary of the United Operative Cabinet and Chair-makers Society of Scotland). ${ }^{5}$

All these people were discussing the idea of trying to teach Socialism to children and Margaret MacMillan took up the writing of a primer which she never finished. ${ }^{6}$ Again it is most significant that the stimulus was coming from a consciousness of failure to make an impact on the working-class electorate. This, at any rate, seems to have been in the mind of Lizzie Glasier when she wrote to the Labour Leader canvassing the idea of forming Socialist classes for children in connection with "every branch of the I.L.P. and other Socialist bodies throughout the country."

"Effort ought to be made (she insisted) to get at the little ones

${ }^{1}$ Labour Leader, Apr., I893. I am grateful to Mr. J. Simmons for this and other references to the Labour Leader.

2 Labour Leader, May, 1893.

3 Ibid., July, 1895.

4 See article by L. Glasier in YS, Jan., 1906.

5 Ibid. For the details of McArthur's early life mentioned in this article $I$ have telied on the recollections supplied to me by an early acquaintance, Mr. D. Jarvis, of New York. For Gossip, cf. S. Harrison, Alex Gossip ( 1962 ), especially ch. I.

- Labour Leader, 25 May, 1895. Cf. YS, Jan. 1906. 
when their minds and susceptibilities are plastic and impressionable."1

Practical impetus was given to these discussions by the arrival in Glasgow to study at the University of Caroline Martyn, ${ }^{2}$ yet another of the ILP Socialist lecturers. It was probably Caroline Martyn who proposed that the Crusaders' class should be called a sunday school, for she had had a high church upbringing as well as an early training as a schoolteacher. It was she at any rate who, on Sunday, February 2, I 896 , summoned a meeting of interested people and formed the Glasgow Socialist Sunday School. Caroline Martyn became its secretary.

The modern Socialist Sunday School movement is to be dated from this Glasgow inception and the personalities concerned in it are worthy of some further consideration. They were imbued with a sense of conversion to a new religion, or at least to the re-interpretation of traditional religion. Caroline Martyn herself claimed to have learned all her social theories from the New Testament. Archie McArthur, then about forty years of age and working as a stair-railer, had early hoped to be ordained but had failed to complete his degree. He had been President of a body known as the Glasgow Christian Socialist League $^{3}$ before he became associated with the Labour Army, a kind of Socialist lecture society. ${ }^{4} \mathrm{~A}$ prominent figure in the literary society of a Glasgow parish church he had gathered round him a band of young men and women whom he brought to challenge the spirit of Christian orthodoxy and who later became active in the Socialist Sunday School movement.

By I 895 McArthur had abandoned Christianity but, like Thomas Carlyle in whose works he had steeped himself, he retained a profound reverence for the language of its ethics. From Carlyle he obtained the conception of a kind of agnostic religion, agnostic as to belief in God but involving faith in the perception of transcendent moral law. In an address given to a Glasgow Socialist Sunday School in I 900 he said:

"If you break a moral law, not the law written in the Bible but the law written in our natures, stamped on our very beings, if you break that law you will be punished. If you keep it, the result is peace and happiness."6

${ }^{1}$ Ibid.

${ }^{2}$ For Caroline Martyn see biographical notes in YS, Jan., 1906 and July, 1926. Cf. Labour Annual, 1896.

a Y, Aug. I903.

4 D. Lowe, Souvenirs of Scottish Labour (Glasgow, I919), pp. 97 ff.

5 YS, Aug., rgo3.

B A. McArthur, Farewell Address to Central S.S.S. (1900, Ms. in library of Glasgow and District Union of Socialist Sunday Schools). 
He saw bad social conditions and the suffering consequent upon them as resulting from the actions of those who did not keep "the law written in our natures," but the people so stigmatised were not the workers, not the improvident, shiftless good-for-nothings of selfhelp propagandists, but the capitalistic exploiters of industrialism and it was the duty of Socialists

"to see to it, that, in the years to come, not that we pass Acts for the protection of Labour, but that we take industry out of the hands of those men who, all along, have used it for their own interests and not for the commonweal."1

Here, of course, McArthur parted company with Carlyle in seeing Socialism as the ideal society, but in insisting upon the arguments of romantic idealism he had invoked the most radical theme of Carlyle's vision and he went on to assert that proper ethical conduct was necessary to the attainment of the ideal society:

"You will hear social reformers, and especially Socialists, speaking about the environment and the necessity of changing the environment as if it were the only necessary change. Others speak as if all you had to do in order to solve this great, puzzling problem was simply to change the man himself, change his heart and spirit. Now I would impress upon you that both these views are one-sided, therefore they are wrong.Each is simply a part of the whole truth. In order to solve this great social problem, we must have both external change and internal change."2 Thus at the foundation of the Socialist Sunday School movement MacArthur clothed it with the teaching of a "labour sect". He it was who insisted that Socialism involved adherence to a system of ethics and this system, in which love was the cardinal virtue, echoed the phraseology of traditional Christianity: Thus, young Socialists should "build up the City of Love in our own hearts and so, by and by, help to build it up in the world". ${ }^{3}$ In course of a very short time, Socialist Sunday School workers came to think and speak of Socialism not only as a system of ethics but as a religion, thus confusing terms in a way which shocked theologians then and since. More serious for the future of the movement, perhaps, was the danger that lay in the use of this traditional language. McArthur was clear that love was an affinity to be felt by the Socialist for all those who suffered from an unjust system of society. It was not long before some members of Socialist Sunday Schools felt that some of those who used the language

${ }^{1}$ A. McArthur, Lectures Delivered to the Young Socialist Guild. Ms. in library of Glasgow and District Union of Socialist Sunday Schools.

2Ibid.

'YS, March, I90I. 
of ethics were losing sight of the just society and extending their charity to its enemies. But this is to anticipate; first we must see how the movement spread from Glasgow.

From March, 1897, McArthur took over from Keir Hardie the editing of the Crusaders' column in the Labour Leader. ${ }^{1}$ This put him in the position of a kind of national organiser of labour sunday schools. By 1900, largely thanks to his enthusiasm, there were seven Socialist Sunday Schools in Glasgow and one each in Paisley and Edinburgh. ${ }^{2}$ He was corresponding, moreover, with four sunday schools in London. He received also reports from four sunday schools in Yorkshire, three run by Labour Churches and one by the ILP. ${ }^{2}$

The years before the First World War saw a remarkable expansion of the movement. If the ILP was the political heir of the Labour Churches, Socialist Sunday Schools as conceived and developed by McArthur became the wearer of their sectarian cloth. Just as the emergence of the Labour Churches coincided with the upsurge of independent labour politics in the early nineties, so the expansion of the Socialist Sunday School movement in the twentieth century coincided first with the growth of political radicalism in the years after the South African War and preceding the General Election of 1906 , and second with the rise of industrial militancy in the years I9ro-II. The age of the labour sect was by no means over when the expression of class-consciousness could still, in the Edwardian era, lead so many into enthusiasm for social and ethical teachings derived (albeit by ignoring the ambiguities) from traditional religion. Socialist Sunday Schools, however, while they could provide the opportunity for this kind of expression had the additional purpose of aiming at the conversion to Socialism of the young, the working-class electorate of tomorrow. Having therefore an instructional aspect to their activities, they attracted not only the kind of men and women who had attended the Labour Churches for the devotional experience, but also young men and women, converts to Socialism, who were interested in educational techniques. Among this latter group were to be found professional school teachers who, frustrated by the impoverished barrenness of much of the State school system, found in Socialist Sunday Schools an opportunity for experimenting in the

1 "Chats with Crusaders", in: Labour Leader, March, 1897.

2 Labour Leader, Sep., 1900. 
teaching of history, civics and ethics. As a result a considerable body of pamphlet literature was produced by the movement in this period which throws a good deal of light upon the sectarian character of Socialist Sunday Schools in these years and on the unsuccessful struggle waged within them to remove the ethical element from their teaching.

In the atmosphere of growing radicalism after the South African War, Socialist Sunday Schools underwent their first main expansion. During the election of 1906, attendance at Huddersfield SSS in Yorkshire rose on average from about a hundred to over four hundred. ${ }^{1}$ A similar growth took place in the four main centres of the movement. By 1906 Glasgow had ten sunday schools, Edinburgh two (Scotland fourteen in all), Yorkshire eight and Lancashire five. ${ }^{2}$ The most remarkable growth was in London which in 1907 was said to have at least twenty sunday schools. ${ }^{3}$ Success here was due in no small measure to the personal intervention of McArthur and Gossip. McArthur had moved from Glasgow to London in 1900 . He found the handful of London sunday schools mouldering from lack of enthusiasm and threw his energies and enthusiasm into the work of revitalising them. In doing so he gave the movement in London the same ethical outlook and sectarian character as he had left behind in Glasgow. In 1902 he was joined by Gossip who had just been appointed assistant-secretary of the new Amalgamated Furniture Trades Association. Gossip's trade union status gave him a certain prestige with the London ILP and the support of that body for Socialist Sunday Schools in London was notably stimulated as can be seen by its publishing in 1902 a little volume by Katherine Bruce Glasier entitled $A$ Child's Socialist Reader. ${ }^{4}$

Success in London brought publicity and this invited attack from anti-Socialist quarters. In 1902 The Times attacked Socialist Sunday Schools for trying to influence the next generation of electors. ${ }^{5}$ In the London County Council elections of November, 1906, the local press in London drew attention to the fact that four Socialist Sunday Schools met on Sundays in the school premises owned by the Council. The heavy defeat of the Progressives (the Radical and Fabian alliance) robbed the Socialists of their patrons on the Council and left them

${ }^{1}$ Independent Labour Party, Annual Confetence, 1919, Souvenir Programme (Huddersfield, 1919).

2 YS, Feb., 1906.

Ibid., Feb., 1907.

4 Harrison, Alex Gossip; G. Bruce Glasier, A Child's Socialist Reader (r902); YS, June, I902.

5 YS, Sep., 1902. 
exposed to attack by a motion for their eviction which was strenuously debated in the Council chamber. Forced to defend themselves, the Sunday Schools claimed that they existed for the purpose of teaching the religion of Socialism - an early example of the use of the expression. Conservatives on the Council retorted bluntly that they taught not religion, but Socialist politics. Some of them on visiting the schools had found children singing "The Red Flag" and "The International". In spite of the charge by Sidney Webb, Frank Smith and others who defended the Sunday Schools in the debate that the Council in evicting these Sunday Schools would be setting up to decide what was and what was not a religion, the majority voted for eviction. ${ }^{1}$ The upshot of this was a good deal of publicity for Socialist Sunday Schools which was increased by a large demonstration in Trafalgar Square addressed by J. O'Grady, the Labour MP and other prominent Socialists. $^{2}$

The London storm was significant because it fostered an already growing feeling in favour of establishing a national Socialist Sunday School organisation. In January, 1901, McArthur had provided a strong unifying influence by the establishment of a monthly magazine, the Young Socialist. Its first two issues were mere typescript sheets but, when he relinquished the editorship to go abroad in January 1904, the magazine had a circulation of over one thousand, and eight printed pages for a halfpenny. ${ }^{3}$ It published reports of the progress of the movement in all localities and so gave Sunday Schools a sense of national cohesion.

Two further circumstances demanded national organisation. First was the desire to have a common hymn book for use in all Socialist Sunday Schools since the Labour Church Hymn Book thus far used was falling into short supply. Second, there was need for a national body that could affiliate to the International Federation of Young People's Organisations set up on the Continent in 1907 and actively taking up the cause of antimilitarism.

The major obstacle to the formation of a national organisation was finance, but the London troubles convinced most Sunday School workers that the effort would have to be made, if only the better to defend themselves when attacked. In order to describe the body brought into being it is necessary first to give some account of the organisational structure hitherto developed by Socialist Sunday Schools. The unit of organisation was the Sunday School itself

\footnotetext{
${ }^{1}$ For the campaign to evict the Sunday Schools see YS, Apr.-May, 1907. For the debate in LCC see The Times, 12 June, 1907.

2 The Times, 20 July, I907.

3 YS, Jan., I904.
} 
whose membership was open to any interested adult persons who were expected to acknowledge themselves generally as Socialists. The governing body of the Sunday School was the assembly of all members, management being in the hands of an executive elected by the membership.

Very early, Sunday Schools in the same district began to form themselves into Unions. These Unions co-ordinated activities, drawing up lists of people willing to teach in Sunday Schools, providing a forum for the discussion of methods, organising joint activities and sometimes taking the initiative in the formation of a new Sunday School or coming to the rescue of others in financial crises. The district covered by a Union was either a town or county or part of a county. In Glasgow, Edinburgh and London, the earliest urban Unions, the membership of the Union was open to every member of a Socialist Sunday School in the area covered. In practice each Sunday School was represented by delegates at the monthly meetings of the Unions, but an annual general meeting of all members was always held. In the North of England, where Sunday Schools were scattered over wider areas, the Sunday Schools in Lancashire and Yorkshire held half-yearly delegate conferences. In I905, Lancashire and Cheshire jointly formed a Union separate from that of Yorkshire. ${ }^{1}$ By 1909 there were five Unions: Glasgow, Edinburgh, London, Lancashire and Cheshire, and Yorkshire.

In response to the needs already touched upon, these Unions came together in 1909 to form the National Council of British Socialist Sunday School Unions. ${ }^{2}$ Under its constitution this body was a council for joint consultation rather than an institution of central government. The problem of finance would at this time have prevented the creation of a highly centralised body. The Council was to be composed of two delegates from each Union. It would meet annually, but would have no executive committee, appointing a new chairman, secretary and treasurer at each conference. The further expansion of the movement in the years before the First World War, therefore, owed little to the creation of the National Council and everything to the upsurge of industrial militancy in I910. New Sunday Schools were being opened everywhere and old ones were increasing their membership in spite of bitter attacks from anti-Socialists. ${ }^{3}$ In 19 r 2

1 YS, Nov., igos.

${ }^{2}$ For a report of the inaugural conference see YS, June, I909; also a summary of the constitution.

${ }^{3}$ YS, July-Aug., 19 ro for an account of the formation of a rival Children's Social Sunday Union by members of London high society. Cf. ibid., Oct., I9 10 for attacks in Huddersfield. 
there were six Unions (Tyneside being the latest addition) with at least 96 Sunday Schools affiliated to them: fifteen in Glasgow, eight in Edinburgh, twenty in Yorkshire, twenty-one in Lancashire, eighteen in London and four in Tyneside. In addition there were twelve Sunday Schools not affiliated to any Union. The total attendance at these Sunday Schools was given thus: children, 4,540; adolescents (seventeen to twenty-one years), 1,788 ; adults, $6,328.1^{1}$

\section{III}

The loose-knit character of the Socialist Sunday School movement was not merely due to its geographical diffusion or to lack of finance. At the inaugural conference of the National Council in 1909 there was a clearly-expressed distrust of over-centralisation due to a cleavage of aims and outlook which had grown up between Sunday Schools centred mainly in Lancashire and the rest. We have already noted the roots of the cleavage in, on the one hand, the resolution of the Manchester Cinderella workers and, on the other, the teaching of Archie McArthur. Where the former aimed at fostering in children an understanding of the social conditions in the world around them, the latter insisted that this was not enough and sought to awaken emotions which were thought necessary to the bringing about of any transformation of society. By the early twentieth century this division of opinion had given rise to two distinct schools of thought.

The school of thought which emanated from Glasgow was also accepted in London and Yorkshire. ${ }^{2}$ MacArthur had done much to set the tone in these Sunday Schools. His early church adherence and his idealist conception of Socialism disposed him to regard the Sunday School as a gathering for devotional exercises for the cultivation of emotions appropriate to the co-operative mode of life. In the early days in Glasgow, men, women and children gathered together on a Sunday morning under the chairmanship of a "Superintendent". Since one of the objects of Socialist Sunday Schools was to train boys and girls to take their places as leaders in the working-class movement, the children were encouraged to undertake minor offices. It became usual, for instance, for one of the children to make a minute of each week's proceedings. The atmosphere at such gatherings was ideally expressed by a writer in the Young Socialist in 1905. Speaking of the

\footnotetext{
1 Ibid., Apr., 19I2. The list given here was said to be incomplete.

2 Sunday Schools in Yorshire were founded by Labour Churches, but the anti-religious influence of Blatchford does not seem to have had as much effect upon them as upon those in Lancashire.
} 
Superintendent of a Glasgow Sunday School and his wife, he declared that they "carried an atmosphere of deep religious conviction into their work for Socialism, an air of gentleness and refinement that was the outward evidence of an inward grace." 1

A feature of the Sunday meeting was the singing of hymns from the Labour Cburch Hymn Book or, later, from the Socialist Sunday School Hymn Book. One favourite ran in part:

"We're a band of little comrades,

Walking in the path of Truth;

We are marching onward, onward,

Through the flowery land of youth;

Marching onward up to manhood,

When we mean to join the fight,

Of the weak against oppression,

In the battle for the Right."2

Usually the meeting commenced with the whole assembly standing to repeat the following "Aspiration":

"Love, we give ourselves to thee.

May we live in Thy spirit all this day,

In our work and in our play,

In our joy and in our sorrow,

Wherever we are and whatever we do,

May we live in Thy spirit all this day,

Till the shadows of evening fall about.

Love, we give ourselves wholly to Thee,

Now and forever."3

The quality of prayer is unmistakable in this as in the similar Aspiration used to end the meeting.

The central feature of the meeting was the "Lesson" given by the Superintendent or by another adult member of the Sunday School.4 These were nearly always on some question of ethics: "Gambling", "Happiness", "Sports and Pastimes", "Companionship", "Self-Help", "Self-Reverence" being the first in a list of reported Lessons at a Glasgow Sunday School during $1909 .{ }^{5}$ McArthur's Farewell Address to Central Socialist Sunday School, Glasgow, already quoted, suggests that the Lesson was sometimes aimed as much at the adults as at the children present.

I YS, Jan., I905.

2 Socialist Sunday School Hymn Book, No. I 2.

${ }^{3}$ Ibid.

${ }^{4}$ From the beginning a prominent Socialist such as Keir Hardie would give the lesson on a special occasion. Quite early, the practice of inviting members from other Sunday Schools was initiated.

5 YS, Jan.-Feb., 1905 . 
Further sectarian colour was added to the movement by the publication in $190 \mathrm{I}$ of the Socialist Ten Commandments ${ }^{1}$ which became very popular with Sunday Schools in the Glasgow tradition. These relied heavily on the Christian tradition as is to be seen from their language: "love", "righteousness", "commandments". Behind the language, however, lay class-conscious aspirations.

"7. Remember that all the good things of the Earth are produced

by Labour. Whoever enjoys them without working for them is stealing the bread of the workers."

Devotional exercises on Sundays were supplemented by other characteristically sectarian activities. The reading of suitable texts was encouraged and McArthur ran a course of lectures for the adolescent members of Central SSS, Glasgow, on the works of Carlyle and on world history. The manuscript of these lectures from which quotation has already been made shows that the works referred to were Chartism, Past and Present, Heroes and Hero-Worship and Sartor Resartus. In addition, the Sunday Schools became the centres of vigorous communal activity. Some Sunday Schools ran children's orchestras. Choral singing and folk dancing were fostered and Unions ran festivals of music and dancing which attracted audiences much wider than their membership. Country rambles by means of the cheap tram-ride from the towns were organised. Unions ran sports competitions. Never far below the surface in all these activities was the desire to improve the moral, mental and physical state of the children. They were taught the art of cheap and simple, elegant dress-making, and Margaret MacMillan contributed many articles on this subject to the Young Socialist. Sunday Schools and Unions built up libraries, for the use both of children and teachers.

As this sectarian pattern developed in the Socialist Sunday School movement it began to fall under increasing criticism, even in Glasgow. ${ }^{2}$ Its limitations and weaknesses were most obvious to younger men and women recruited to the movement after 1900 . They found in the Sunday Schools a somewhat cliquish atmosphere and signs of a "Sunday-best" respectability in the dress of those who attended. Favoured speakers tended to establish themselves in a kind of preaching-circuit round the Sunday Schools and the lessons which they gave on the duties of the young Socialist seemed to have insufficient relevance to the everyday problems of working people. It was coming to be felt that the instruction given sacrificed an under-

2 See Appendix I.

2 In an interview with Mr. Allan Ireland, Glasgow, I obtained reminiscences of Glasgow Socialist Sunday Schools at the turn of the century which lend colour to the evidence of printed sources as to the sectarian character of the movement. 
standing of the economic relations of society to an instilling of altruistic emotions which had never been the monopoly of workingclass people and which might be as relevant to a non-Socialist as to a Socialist system of ethics.

These critics did not object fundamentally to the view that conversion to Socialism meant conversion to a new ethic. What they insisted upon was a clearer statement of the social and economic aims of Socialism and they prevailed upon the Glasgow Union to draw up, in 1908, "Declarations of the First Principles of Socialism". The adoption of a catechistic form for this document ${ }^{1}$ shows how little the critics had broken with the sectarian spirit, but the preliminary draft of the text ${ }^{2}$ showed a marked determination to avoid sweeping ethical statements. However, the influence of traditional ethical language was powerful in theology-soaked Scotland and the text finally published contained at the end a strong flourish towards the rhetoric of the religion of Socialism.

The publication of the "Declarations of First Principles" did not allay the criticism in Glasgow for, in $19 \mathrm{r} 1$, a founder-member of the Glasgow Socialist Sunday School, T. Anderson, a militant trade unionist and "ardent Socialist of the Karl Marx school"3 brought about a minor secession by organising a "Proletarian" Sunday School. ${ }^{4}$ His aim was clearly to foster in children a militant classconsciousness, but his personality was an unattractive one and he drew few supporters away from the Socialist Sunday Schools.

Meanwhile Socialist Sunday Schools in Lancashire were developing an attitude to the teaching of Socialism which was independent of the language and outlook of traditional Christian ethics. The Sunday Schools here had grown up as fringe activities of the Labour Churches and were usually run by a committee of church members. The committees appointed teachers to instruct the children, who met separately from the church congregation in classes graded according to age. As the Lancashire Labour Churches withered in the late nineties the committees which ran the Sunday Schools frequently remained as the

1 See Appendix II.

2 YS, Aug., 1908.

${ }^{3}$ Ibid., May, rgo6.

4 Little is to be learned of the split or of the secession movement. According to Mr. A. Ireland the occasion of the split was a trivial matter of personalities. Proletarian Sunday Schools survived here and there to horrify right-wing opinion. A former member of a Proletarian Sunday School in Glasgow in the I930s told the present writer that she was taught to sing abusively anti-clerical songs. This would seem to corroborate some of the allegations made in a debate in the House of Commons on Socialist Sunday Schools, Hansard, I I th March, 1927, where some of the more hostile Conservatives obviously confused Socialist and Proletarian Sunday Schools. 
only evidence that the churches had ever existed and provided nuclei around which strength could grow in the later phases of radical discontent among the working class in the twentieth century. This was the case, for instance, with the Labour Church Sunday School which met at Booth Street, Manchester, in 1898 . By 1901 , according to the Young Socialist, "the vanished control of the Labour Church is likely to be replaced by that of a strong working committee and the

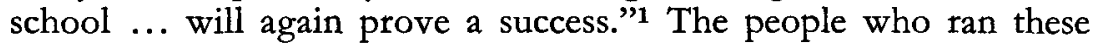
Socialist Sunday Schools in Lancashire adhered to a kind of Socialism which had little time for ethics. Their social analysis owed much to the Marxism of the Social Democratic Federation which was strong in that part of the country and their outlook on questions of ethics was influenced by the adhesion to Determinism of their own Socialist prophet, Robert Blatchford, author of Merrie England. ${ }^{2}$ Prominent among these Lancashire Socialists was a number of young professional schoolteachers who were ready, indeed eager, to experiment with their new ideas both in education and politics.

We know most about this phase as it affected Hyde SSS which was run by what had come to be called Hyde Socialist Church. ${ }^{3}$ The children attending this Sunday School were divided into five classes according to age. In the classes for the youngest children juvenile fiction and nature study were taught as a means of laying the foundation of a factual understanding of the world. For the older children there were tales of bygone reformers and the reading of historical novels, calculated to awaken a sense of human progress. After the age of thirteen, when the child would normally be working for wages, he was expected to grapple with and come to an understanding of the relation between capitalism and bad social conditions. At sixteen boys and girls were separated for instruction in sexual ethics. Thereafter the young socialist graduated into the adult class which met separately to discuss literature on history, economics and socialism.

The aim behind this elaborate curriculum was close to the objective outlined by the resolution of the Manchester Cinderella Club workers. The object was to demonstrate that Socialism was an inevitable stage in the evolution of society. This, it was believed, was a matter of rational comprehension. Ethics could have no primary place in the scheme of education since ethical attitudes were socially determined.

\footnotetext{
1 YS, Nov., Igor.

2 On the SDF in Lancashire see F. Bealey and H. Pelling, Labour and Politics, I900-1906 (1958), pp. 3f. On the development of Blatchford see G. D. H. Cole, The Second International, I (1956), pp. I $6{ }_{3} \mathrm{ff}$.

${ }^{3}$ For a full description of Hyde SSS see G. M. Whitehead, Education in Socialist Sunday Schools; A Contribution (Hyde, 1910).
} 
"Our basic principle, therefore, is Evolution. Our economic doctrine is Socialism. Our moral conceptions are those embodied in the theory of Determinism."

And again;

"Our duty, however, is not to inculcate kindness, generosity and kindred virtues as final goals; ... We have to get at the causes underlying all social manifestations, or at least as many as possible."1

What is important here is not the demonstrable weakness of the case ${ }^{2}$ but the extent of the breach with the language and outlook of traditional Christian ethics which still dominated Sunday Schools in other parts of the country as can be seen from their pamphlet literature.

An attack on Socialist Sunday Schools by orthodox church circles in Glasgow on the grounds that they were irreligious provoked a reply from Lizzie Glasier in $1907 .^{3}$ In the course of a short pamphlet she denied that there was any distinction to be drawn between religion and ethics and claimed, therefore, that Socialist Sunday Schools, in trying to teach the ethics of Socialism, were teaching the religion of Socialism. In 1908 a pamphlet published in Yorkshire presented the same viewpoint, but set out a more systematic course of ethical instruction. ${ }^{4}$ It is therefore not surprising that the conference which met in 1909 to draw up a constitution for the proposed national organisation of Socialist Sunday Schools saw a sharp cleavage of opinion when it came to defining aims. Division emerged over the use of the word "secular" to describe the teaching given in the Sunday Schools. The "religious" group maintained that it was "associated in the minds of many people with secularism". 5 The issue was so hotly debated that it had to be referred to a sub-committee composed of two Lancashire and two Glasgow delegates which provided an acceptable compromise amendment describing the teaching of the Sunday Schools as "non-theological in character, paying exclusive attention to the present life and its duties."6 Such obvious disagreement provided a strong reason for not according to

1 Ibid.

2 This lay in the failure to show why Socialist education was necessary. If social attitudes were determined by the environment, why should it be important to try to foster an understanding of social relationships? This could be of importance only if intended to influence individual decisions.

9. Glasier, A Reply to the Sabbath school teacher's Magazine (Glasgow, I 907).

4 D. Walford, Socialist Sunday Schools; Their Aims, Value and Future (Huddersfield, I908).

5 YS, June, 1909.

Ibid. 
the new Council any powers of central control, and its functions, apart from "assisting in the formation of new S.S.S. Unions where groups of Sunday Schools already exist", were strictly limited to the preparation of literature for publication under the injunction that "all matters relating to methods, literature, etc. must be submitted to the Unions for adoption."1

Disagreement continued to be expressed through I9IO and I9I I. Hyde SSS published their views in a pamphlet already quoted. In the same year, I9ro, the National Council found itself unable to agree on the contents of a pamphlet setting out the "aims and objects" of the Socialist Sunday Schools and, in I9II, decided to postpone publication indefinitely. ${ }^{2}$ When the long-awaited Socialist Sunday School Hymn Book was published in I9I I, it was thought necessary to separate the purely ethical hymns in the volume from the "Socialist" hymns which were thought to contain an economic strain. Among the Socialist hymns was William Morris's old revolutionary favourite, The March of the Workers. In I 912 controversy was carried into the pages of the Young Socialist, where a member of Hyde SSS pointed out that the teaching of mere altruism was as likely to produce young Liberals and young Unionists as young Socialists. Education in Socialist Sunday Schools, he contended, "should create of our children when they attain to adult life an army of Socialists" intellectually equipped to "consciously guide their fellows towards emancipation". ${ }^{3}$ This prompted the retort from a Glasgow member that the writer was throwing away the gold of the moral appeal with the dross of orthodoxy. "Man does not live by bread alone, and logic alone never yet made a Socialist."4

There was little danger of the controversy developing into a split. The religious or ethical wing was decidedly in the majority, having influence over most of the Sunday Schools outside Lancashire. On the other hand, since the new National Council had few formal powers, there was no need for the Lancashire Socialists to press their views at that level. Meanwhile, as we have seen, the number of Socialist Sunday Schools continued to increase in the mood of militancy of the years preceding the First World War. Throughout this period the religious wing had control of the Young Socialist through the tenure of the editorial office by Lizzie Glasier. She took a lively interest in current affairs and expressed her views as those of the movement. Her ethical view of Socialism did not make her noticeably moderate,

${ }^{1}$ Ibid.

2 YS, Apr., I9II.

3 YS, Aug., rgr 2.

4 Ibid., Oct., I912. 
for she was outspoken in support of the workers' demands in the strikes involving seamen, dockers, railwaymen and miners in I9II-12.

In the years immediately before the War, the religious wing was powerfully supported from a new quarter, London Positivism. The Positivist lecturer, F. J. Gould, had obtained some celebrity as a propagandist for Comte's Religion of Humanity and, as a member of the School Board in Leicester, had campaigned for the introduction of non-religious moral instruction in State schools so as to break the monopoly enjoyed by Christian teaching. ${ }^{1}$ In I910 he moved to London to work for a body called the Moral Instruction League and began to interest himself in various non-Christian sunday schools there, including those run by Brotherhood Churches, the Ethical Sunday School movement, as well as by the Socialists. His aim was that all these bodies should be transformed into vehicles for the propagation of humanist religion. As a teacher and writer for children Gould had an excellent style and he was soon contributing regularly to the Young Socialist. ${ }^{2}$ In I910 he published a pamphlet, Sunday Schools; How to Form and Conduct Them in which he suggested as a model curriculum a course of literature and history based on the lives of heroes, saints and reformers as a means of awakening the moral sense of the child.

As a Positivist, Gould could have no use for Socialism as a religion, though he accepted it as a just economic order. He hoped to win Socialist Sunday Schools over to the general cause of the religion of humanism. In this aim he did not succeed, but his influence was important because it gave to the religious wing of the movement a much-needed systematisation of method and breadth of learning. No doubt this helped it to win acceptance for its point of view in the National Council. In rgr4 the Council finally agreed on a statement of aims and objects. ${ }^{3}$ Based on the pamphlet published in Yorkshire in 1908, this statement clearly endorsed the statement of Socialism in terms of traditional religion, though there may have been a hint of Comte in the statement, "Socialism is essentially a religion, using the term in its strict sense of service and love to humanity." 4 The practical suggestions of the pamphlet as to how and what to teach certainly owed much to Gould's fertile mind and in 1914 he took his place on the Young Socialist Correspondence Bureau, set up by the National Council with the aim of systematising and co-ordinating instruction in

1 F. J. Gould, Life Story of a Humanist (1923), pp. 83 f.

${ }^{2}$ His articles were collected and printed in Pages for Young Socialists (1913) with a foreword by H. M. Hyndman.

${ }^{3}$ Socialist Sunday Schools; Their Aims, Objects and Organisation (1914).

4 Ibid. 
Socialist Sunday Schools on the lines of the statement of aims and

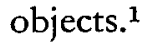

Clearly, then, by I9I4 the Socialist Sunday School movement had inherited the position of the Labour Churches as the working-class sect of British religious life. Indeed, in some ways they had done better than the Labour Churches. Their geographical distribution was not so narrowly confined, though it could scarcely be described as national. In membership they probably exceeded the level attained by the Labour Churches. They continued to give expression to an anticapitalist political ideology in terms of traditional Christian ethics, though just before the War the traditional ethics were clearly being challenged by Humanism which also tended to blur the political ideology by emphasising that moral duties were owed to humanity rather than to the workers as a class.

\section{IV}

The War checked but did not arrest the development of Socialist Sunday Schools. At the outset it caused internal division among members on the issue of support for the War effort. Officially, the movement opposed the War and the igis conference of the National Council adopted a resolution which stated, "The only flag we recognise is the Red Flag and our only War is against Capitalism. We further urge the adoption by the people of an International Court of Arbitration."' In London Alex Gossip helped to organise the appeals of Socialist Sunday School members against conscription, but although many members of the movement were "pacifists" and some went to prison as conscientious objectors to conscription, not a few found the call to the anti-German crusade irresistible. Sunday Schools in Lancashire in particular were severely affected by the drain on their young men, especially in the Liverpool district, while Edinburgh was probably the area in which Socialist Sunday School members were most bitterly divided on the issue. In 1916 and 1917 it was impossible to hold national conferences owing to travel restrictions and the Socialist Sunday School movement which emerged from the War in 19 I 8 was in many respects different from the self-styled religious sect which had entered it in 19 r 4 .

While it temporarily checked the growth of Socialist Sunday Schools, the War brought them a number of special opportunities.

2 YS, May, I9I5. 
Its "pacifist" position induced the ILP to take a closer interest in it than formerly. Many people who felt themselves to be social outcasts because of their opposition to the war found in Socialist Sunday Schools a congenial social outlet. After the first check, the number of Sunday Schools began again to increase, particularly in the West of Scotland, an area of the country where militant opposition to the War and probably to capitalism itself was more than usually deeprooted. For many members the War brought higher wages and this meant for the movement higher income from subscriptions. In the continued relative prosperity of the short post-War boom, a period also of buoyant radicalism in politics and industrial affairs, the Sunday Schools shared in the membership expansion of the ILP. ${ }^{1}$

However, the new membership of the post-War era had a new look. Many of the young men and women drawn into the Sunday School movement by the War adhered to the emerging left wing of the ILP which was to form in the I920s a continuous left opposition to the official leadership of the Labour Party. In 1920 some of the members joined the new Communist Party of Great Britain and although, in I922, the CPGB formally dissociated itself from the Socialist Sunday School movement, ${ }^{2}$ the Secretary of the National Council appealed to their Communist comrades to continue to support the Sunday Schools and many did so. Alex Gossip, one of the few foundermembers of the movement to become a Communist, retained a close association with Fulham SSS, London, throughout the period under review and regularly wrote in the Young Socialist under the pen-name, "Kalek".

It is not surprising, therefore, that in the 1920 s yet another cleavage of opinion developed within the Socialist Sunday School movement. This time the dispute was between the new militants and the oldstyle idealists and turned on the value of the Socialist ethics which had formerly been expressed mainly in the language of Christianity. The decade that saw the General Strike of 1926 and the imprisonment of Labour councillors in London for defying a court order respecting relief of the unemployed (I92I) seemed to demand emphasis on disciplined class-consciousness and intensified militancy. Their attitude, however, unlike that of the Lancashire Socialists before the War, did not amount to a rejection of the ethical approach to Socialist teaching. The new militants wanted to stress different ethical standards and were impatient of the talk of Love and Righteousness. This impatience was not altogether unjustified since many of the older

1 Cf. A. J. B. Marwick, “The Independent Labour Party in the r920s", in: BIHR, XXXV, pp. 62-74.

2 YS, Jan., 1922. 
members seemed to have forgotten that the religion of Socialism as originally conceived by founders like McArthur entailed the practice of Socialist duties as between workers but not on the part of the worker towards those who "steal the bread of the workers". By the I 930 s the militants were in the ascendant and the Socialist Sunday School movement spoke with their voice. In the meantime, however, economic depression, the plague which had weakened every workingclass sect since the days of the Primitive Methodists, in the early nineteenth century had sapped the resources of the movement and the glory, if not departed, was greatly dimmed.

In 1918, however, these developments lay in the future. What seemed important was to consolidate the new strength gained in the latter years of the War and to take up the development of a system of Socialist moral instruction which had been flowering so promisingly in 1914.

The ten Unions ${ }^{1}$ embracing 149 Sunday Schools in 1920 had become unmanageable by a part-time, voluntary secretary. The annual conference of 1920 , therefore, resolved to change the constitution of the National Council from that of a body of affiliated Socialist Sunday School Unions to one of affiliated Sunday Schools. ${ }^{2}$ Each member Sunday School would pay an affiliation fee of threepence per month for each of its members. The scheme was intended to raise sufficient revenue to enable the new National Council of British Socialist Sunday Schools to establish a paid secretaryship. It was doomed to failure, not because of parsimony or apathy on the part of the members but because of the financial strain placed upon them by the unemployment of the depressions of 1920 and 1931. As Socialist Sunday Schools became associated with the more extreme wing of the divided British Labour Movement, their numbers began to decrease. As economic adversity hit their members, the possibility of building up a sound national organisation vanished. In 1921 , the first year of operation of the new constitution, 96 out of 153 Sunday Schools were affiliated to the National Council, but income had not proved sufficient to justify appointing the much desired full-time secretary. ${ }^{3}$ By the end of the slump in 1923 , there were only ${ }_{130}$ Sunday Schools in existence and only 67 were affiliated. ${ }^{4}$ Relatively

\footnotetext{
1 These were: London, Lancashire and Cheshire, North-East Lancashire, Yorkshire, Tyneside, South Wales, Ayrshire, Edinburgh, Fife, Glasgow. Cf. YS, May, 1920.

2 Ibid.

${ }^{3}$ Log Book of the National Council of British Socialist Sunday Schools, Ms. in the possession of Mr. J. Simmons.

4 Minutes of Annual Conferences of the National Council of British Socialist Sunday Schools, 1923. Typescript in the possession of Mr. J. Daly, Glasgow.
} 
better economic conditions after 1923 brought an improvement in the number of Sunday Schools affiliated which rose to 85 in 1927, but the absolute number of Sunday Schools fell to I $13 .{ }^{1}$ This figure of existing Sunday Schools was disappointing particularly because in 1924 a sustained propaganda campaign, including the issuing of a manifesto appealing for support to all Socialist and Labour bodies, had been carried out. James Maxton and George Lansbury, prominent leaders of the left opposition in the Parliamentary Labour Party were among the signatories of the manifesto which was signed by thirty-five other Labour MP's. ${ }^{2}$ As in the pre-War days, the movement was probably assisted by the attacks of its enemies. An extreme right-wing body, the British Empire Union, mounted an offensive against the Sunday Schools and in 1924 had a Bill introduced in the House of Lords which proposed to subject to summary prosecution those who taught "seditious and blasphemous doctrines" to children. ${ }^{3}$ Though the Bill passed all its stages in the Lords, it made no further progress with a Labour government in office. It made another unsuccessful appearance in the House of Commons in 1927 , the year after the General Strike. ${ }^{4}$

Simultaneously with the re-organisation of 1920 went a renewal of the attempt to systematise and co-ordinate the moral instruction given in Socialist Sunday Schools. To this end a manual for teachers was published in $1923 .{ }^{5} \mathrm{~F}$. J. Gould's association with the movement had virtually ended when he disagreed with the Socialist Sunday School leadership and lent his support to those who backed the declaration of war on Germany. The manual of 1923, however, owed much to his methods of systematic moral teaching. Yet it was no Positivist tract and insisted on the traditional view that Socialism constituted a distinct religion.

What is remarkable about this publication is that it never achieved wide acceptance in the Socialist Sunday School in spite of its careful drafting. Far from being co-ordinated from the centre, instruction in Socialist Sunday Schools was changing at local level under the influence of the new militancy. The new militants had turned from traditional religious ideology and were now bent on teaching children the moral code of a semi-revolutionary Socialism. At one Glasgow Sunday School during the session 1929-30 there were lessons on the

1 Ibid., 1928.

2 YS, Aug., I925. Another propaganda campaign was carried out with similar support and little success in 1927 . Conference Minutes, 1927.

3 This Bill appeared annually in Parliamentary Papers (Public Bills) from 1922.

4 Hansard, I Ith March, I927.

5 Socialist Sunday Schools; A Manual (1923). 
lives of Lenin, Spartacus, Karl Marx and Keir Hardie ${ }^{1}$ (the lastmentioned of which might have thought himself in strange company, for he had by then become a kind of class-symbol for the Left). While scorning the view that Socialism was a religion, however, they clung to the forms of sectarianism, to the Sunday meetings, the hymnsinging and the catechistic Declarations of the First Principles of Socialism. The roots of centuries-old religious practices were deep in the British working class and difficult to kill.

At the same time the militants carried their spirit into the conferences of the National Council. They were highly critical of the editor of the Young Socialist in the I920s, Miss May Westoby, who had been a personal friend of Lizzie Glasier. Her old-fashioned manner of talking down to children and her habit of dwelling on the value of altruism in the abstract quite outweighed with the militants the virtues of her obvious sincerity and industry and they forced her to resign. ${ }^{2}$

The left wing of the movement was less successful in dislodging the Socialist Ten Commandments from the position of almost canonical authority which they had come to occupy. It may have been the influence of F. J. Gould, who disliked the use of Christian nomenclature, which had brought about the changing of their name to "Socialist Precepts" before the First World War, but their content had remained unchanged. When at the annual conference of 1926 , a London delegate moved for their deletion from the calendar of official literature he failed to find a seconder. ${ }^{3}$ The opening and closing "Aspirations" however, suffered the withdrawal of national endorsement by the conference in $1924 .{ }^{4}$ Another victory for militancy was scored in 1928 when conference endorsed the use of the "Declarations of First Principles"5, until then a document accepted only in Glasgow.

By the end of the twenties the organisation of the movement was clearly weakened by the strains of unemployment. In I 930 there were only fifty-two Sunday Schools affiliated to the National Council. ${ }^{6}$ At the same time, ideological debates within the Labour Party were coming to a head with the onset of the 193 I economic crisis and led to the disaffiliation of the ILP from the Labour Party in 1932. These political events increased the strain between left and right in the Socialist Sunday School movement. A Glasgow Sunday School recorded in 1933 :

1 College SSS, Glasgow, Syllabus (1929).

2 Conference Minutes, 1927.

3 Ibid., 1926.

4 Ibid., I 924 .

5 Ibid., I 928.

6 Ibid., I930. 
"The administrative work of the School was very ably carried out this year, apart from an unfortunate tendency on the part of some of the adult members to bring the ideological battles of the adult movement into the atmosphere of the School."1

At the annual conference of the National Council in 1933 it was reported that political disputes among the membership in Edinburgh had led to children being kept away from Sunday School activities and the president appealed to members to bear in mind that the Sunday Schools had no part in these quarrels. ${ }^{2}$ Though the cleavage between left and right, expressed as it now was in terms of current politics, was real enough, there were no heresy-hunts. The constitution of the movement was still very loose and is would have been difficult to expel a Sunday School from the National Council even if there had been much to gain from such a procedure. Members who did not like the tone of the Socialism taught in their Sunday School could often move to another where the atmosphere was more congenial or simply drop out of the movement.

There can be no doubt that in the late thirties the left wing dominated the movement. It was not yet a purely Communist left. This position would have to wait for the virtual extinction of the ILP after the Second World War. Formal association with the Communist Party, though proffered by the CPGB in "Popular Front" days, was firmly refused and the tone of the Young Socialist, though more sharply militant, remained distinctly non-Communist.

In the period since I9I 8 the character of the Socialist Sunday School movement had greatly altered. The claim to be practising a religion called Socialism had gradually and tacitly been dropped. They now described their teaching as "non-sectarian and nontheological". ${ }^{3}$ Yet if they consciously repudiated the role of the working-class sect, they retained many of the forms and even some of the language of a "Labour Sect" of the I 890 s vintage. They could still provide a focal point for the expression of a general Socialist ethic which might be regarded as extreme but which was nonetheless ethical. Thus it was noted of a Glasgow Sunday School in 1930:

"The School is becoming the nucleus of all Socialist and progressive movements in this district."

They continued to use the "Socialist Precepts" and "Declarations of the First Principles of Socialism" as a basis of the message they were trying to teach and the following passage from the essay on Socialism

\footnotetext{
${ }^{1}$ Log Book of College S.S.S., Glasgow, Ms. in College SSS library.

2 Conference Minutes, I933.

3 Constitution of the National Council of British Socialist Sunday Schools (1932).

Log Book of College S.S.S.
} 
of a fourteen-year old boy shows that the point of their moral objection to capitalism could go home:

"The first part, 'social' means happiness together, while the second part, 'ism', simply notifies a belief or doctrine by which the workers of the world will be lifted to a higher standard of life. Entirely the opposite to Socialism is Capitalism. That means the wealth and luxuries of the country owned by only a small section of the community which is unfair."1

During the r 930 s the signs of decay in the movement are unmistakable. Outside London its main strength had always lain in what were now the distressed areas of high unemployment and the strain of depression was heavier than ever. In the trough of the depression in 1932 the number of Sunday Schools dropped sharply to 69 though the number of affiliated Sunday Schools was stable at fifty-two. ${ }^{2}$ By I 935 , the last year for which figures are available, only thirty-four out of sixty-five Sunday Schools remained affiliated to the National Council. ${ }^{3}$ During the Second World War evacuation disrupted the centres of strength of the movement in the East End of London while social and economic conditions after the War left the movement with little strength outside the West of Scotland where, in conditions of backward economic development, the rump of the Socialist Sunday School movement in Britain lingers on as a symptom of social discontent. ${ }^{4}$

\section{$\mathrm{V}$}

This account of the history of the Socialist Sunday School movement in Britain from 1892 to 1939 suggests that Hobsbawm's description of the phenomenon of the "labour sect" must be extended into the twentieth century. At least until I9I4 - and possibly till I923 - the movement fits easily into the description of the general phenomenon. It drew its following almost exclusively from the working class. Its organisation was ultra-democratic and it gave opportunities of selfexpression to many young people who became, in later life, active in the working-class movement. Furthermore, it expressed workingclass aspirations in the garb of traditional Christian ethics. Even during a period of relatively powerful Positivist influence from 19 ro

1 YS, July, 1929.

2 Conference Minutes, 1932.

3 Ibid., I935.

4 YS, Winter, 1964, contains a directory of seventeen Socialist Sunday Schools, nine of them in the Glasgow area. 
to about 19I4, the movement continued in the main on its traditional course. Gradually, however, in the I920s the Sunday Schools switched their emphasis from the ethics of mutual aid to the ethics of disciplined class-consciousness. The obviously moralistic utterances of the past like the "Aspirations" were dropped and only those early tracts retained which could be given an emphasis more in harmony with the new spirit. In the words of the fourth Socialist Commandment, it now seemed more appropriate to "bow down to none" than to "honour the good". In the thirties this emphasis became finally marked and we have the paradox of a movement of militant Socialists clinging to the out-moded forms of sectarianism - Sunday meetings, the singing of labour hymns and the use of a catechism of Socialist dogma - even while it denied the name of sect.

What gives continuity to the phases of this development and meaning to the paradox is the central aim of the movement which was to convert a significant number of future members of the working class to Socialism. Conversion was the appropriate term because the Socialist was thought to need a new morality. He must turn his back on the competitive spirit. While fostering in his heart a strong spirit of solidarity with other workers he must never display servility before those who claimed to be his social betters. Acceptance of Socialism involved, that is, a moral regeneration as well as an intellectual grasp of economics and history and those who could not accept this, such as the Lancashire determinists, could not fit comfortably into the Socialist Sunday School movement. Children, it was felt moreover, were more susceptible to this moral appeal than adults, already encrusted with prejudice. No doubt there was a good deal of truth in this, but it overlooked the important fact that before the children could be converted the co-operation of their parents was necessary which must, in the nature of the case, involve their conversion to Socialism. Throughout this whole period of their efforts to convert a rising generation to Socialism, the Sunday Schools never stopped to ask themselves how many Socialists they would need to make before they significantly influenced the trend, never asked whether they needed first to convert the parent generation or whether their own reproductive capacities would be sufficient.

Throughout the period covered by this essay, therefore, the movement remained essentially a communion of believers, a sect. If it seems to us astonishing that people should ever seriously have entertained its aim of conversion of a new generation, we should bear in mind the tradition of religious dissent in Britain dating from the seventeenth century. Since then religion and politics had been inseparable in the minds of many. We should remember too that 
popular education had come into existence in Britain as a religious activity on the part of the churches, aiming at the conversion of the little children to the truths of Christianity. It is not, therefore, so surprising that throughout a period when support for working-class political demands seemed inextricably bound up with acceptance of a working-class view of morality, a body should have existed which attempted to give organised expression to that morality in sectarian terms. In our age of political pragmatism and moral relativism, both politics and education have been banished from the spheres of religion and morality. The dominance of this rationalist spirit may account for the fact that a movement so rich in sociological interest as well as antiquarian curiosity as Socialist Sunday Schools should have been all but overlooked by historians of the Working-Class Movement.

\author{
APPENDIX \\ I \\ THE SOCIALIST TEN COMMANDMENTS \\ FROM
}

THE SOCIALIST SUNDAY SCHOOL HYMN BOOK (I9II) life.

I. Love your schoolfellows who will be your fellow-workmen in

2. Love learning which is the food of the mind. Be as grateful to your teachers as to your parents.

3. Make every day holy by good and useful deeds and kindly actions.

4. Honour the good. Be courteous to all. Bow down to none.

5. Do not hate or speak evil of anyone. Do not be revengeful, but stand up for your rights and resist oppression.

6. Do not be cowardly. Be a friend to the weak and love Justice.

7. Remember that all the good things of the earth are produced by labour. Whoever enjoys them without working for them is stealing the bread of the workers.

8. Observe and think in order to discover the Truth. Do not believe what is contrary to reason and never deceive yourself or others.

9. Do not think that those who love their own country must hate and despise other nations, or wish for war, which is a remnant of barbarism.

I0. Look forward to the day when all men and women will be 
free citizens of one Fatherland and live together as brothers and sisters in peace and righteousness.

DECLARATION OF FIRST PRINCIPLES

PUBLISHED BY

THE NATIONAL COUNCIL OF BRITISH SOCIALIST SUNDAY SCHOOLS

Question I. What is our object? Answer. Our object is to realise Socialism.

Question 2. What is meant by Socialism?

Answer. Socialism means common ownership and control of those things we all need to live happily and well.

Question 3. Why is Socialism necessary?

Answer. Socialism is necessary because the present system enables a few to enrich themselves out of the labour of the People.

Question 4. How would Socialism benefit the People? Answer. Socialism would benefit the People as wealth would then be produced for the use of all.

Question 5. What is wealth and how is it produced? Answer. Wealth is everything required to enable us to live and is produced by the work of hand and brain.

Question 6. Will Socialism provide the opportunity of a healthy and happy life for all?

Answer. Yes. Under Socialism there will be neither idle rich nor unemployed poor, but all shall share in the work of the world and in the joy of life.

Question 7. On what principles does Socialism rest?

Answer. Socialism rests on the great principles of Love, Justice and Truth.

Question 8. How can we apply these principles? Answer. By cultivating the spirit of service to others and the practice of mutual aid we can apply these great principles and so hasten the advent of Socialism. 